EESTI NSV TEADUSTE AKADEEMIA TOIMËTISED, 31. KOIDË

FOOSIKA * MATEMAATIKA. 1982, NR. 1

ИЗВЕСТИЯ АКАДЕМИИ НАУК ЭСТОНСКОИ ССР. ТОМ ЗІ

ФИЗИКА * МАТЕМАТИКА. 1982, № 1

удК 621.3.011.71

V. $S A R V$

\title{
ENERGY BALANCE AND VOLTAGE-CURRENT RELATION FOR LINEAR INDUCTORS WITH TIME-VARYING TURNS
}

(Presented by I. Opik)

\section{Introduction}

Inductors can perform their functions in electric circuits due to their energy-storing ability. Therefore the conscious control of energy storing and restoring processes allows a more efficient and versatile use of inductors. For that purpose the variation of the inductance may be used.

A time-varying inductor can be implemented by controlling either the permeance or the turns of the inductor, but it should be pointed out that both the energy flow and the voltage-current relation are different in these two cases. Until now only the voltage-current relation of timevarying inductors with time-varying permeance and time-invariant turns has been considered in the literature. On the other hand, contemporary static switches enable to implement time-varying inductors using stepwise variation of the turns [ $\left.{ }^{1-14}\right]$.

In this paper the voltage-current relation for a linear inductor with smooth variation of turns is derived and discussed. The new relation may be useful for better understanding the performance characteristics of the inductors with time-varying turns as well as an approximate design equation in case of step-wise variation of the turns.

\section{Voltage-current relations}

Let us consider a linear inductor with the time-varying turns $N$, timeinvariant permeance $P$, magnetic flux $\Phi$, current $i$, and voltage $v$ connected to an active network as shown in the Figure.

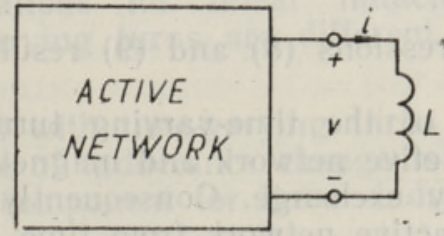

Its time-varying inductance $L$ may be expressed in the form

$$
L=P N^{2}=N \Phi / i \text {. }
$$

The voltage across the inductor is given by Faraday's law as 


$$
v=N \frac{d \Phi}{d t}=N \dot{\Phi}
$$

In accordance with Eq. (1), the magnetic flux

$$
\Phi=P N i .
$$

Since both the turns $N$ and the current $i$ are functions of time and the permeance $P$ is assumed to be a constant, the derivative of the magnetic flux

$$
\dot{\Phi}=P\left(N \frac{d i}{d t}+i \frac{d N}{d t}\right) .
$$

From Eqs. (2) and (4) we obtain

$$
u=P N\left(N \frac{d i}{d t}+i \frac{d N}{d t}\right)=L \frac{d i}{d t}+P N i \frac{d N}{d t} .
$$

Since from Eq. (1)

$$
N=(L / P)^{1 / 2},
$$

we get

$$
\frac{d N}{d t}=\frac{1}{2(P L)^{1 / 2}} \cdot \frac{d L}{d t}=\frac{1}{2 N P} \cdot \frac{d L}{d t} .
$$

Finally, from Eqs. (5) and (7), the voltage across a linear inductor with time-varying turns

$$
v=L \frac{d i}{d t}+\frac{1}{2} i \frac{d L}{d t}
$$

As we can see, the new voltage-current relation (8) for linear timevarying inductors differs from the well-known classical expression

$$
v=L \frac{d i}{d t}+i \frac{d L}{d t}
$$

by the factor $1 / 2$ in the second term. However, there is no contradiction between these two different expressions (8) and (9). They merely correspond to two different modes of energy flow possible in timevarying inductors.

\section{Energy balance}

Physically different expressions (8) and (9) result from different energy conversion processes.

In the above case of the time-varying turns $N$ and unchanging permeance $P$ only the active network and magnetic field of the inductor take part in the energy exchange. Consequently, the energy delivered to the inductor by the active network from time $t_{0}$ to $t$ is

$$
W\left(t_{0}, t\right)=E[\Phi(t), t]-E_{0}\left[\Phi\left(t_{0}\right), t_{0}\right]=\left[i^{2}(t) L(t)-i^{2}\left(t_{0}\right) L\left(t_{0}\right)\right] / 2,
$$

where in the right-hand side of the equation we can see the difference between the energy stored in the magnetic field at time $t$ and at time $t_{0}$, respectively.

Since the instantaneous power of the inductor 


$$
p_{L}(t)=v(t) i(t)=\frac{d W\left(t_{0}, t\right)}{d t}=i(t) L(t) \frac{d i(t)}{d t}+\frac{1}{2} i^{2}(t) \frac{d L(t)}{d t}
$$

we get from energetic considerations again

$$
v(t)=\frac{p_{L}(t)}{i(t)}=L(t) \frac{d i(t)}{d t}+\frac{1}{2} i(t) \frac{d L(t)}{d t},
$$

i.e. an expression identical with (8).

On the other hand, the voltage-current relation (9) corresponds to a time-varying inductor characterized by time-varying permeance and constant turns. In this case not only the magnetic field of the inductor and active network, but also the agent which changes the permeance and via that the characteristic of the inductor, take part in the energy exchange $\left[{ }^{15}\right]$. Therefore, the energy delivered to the inductor by the active network in the time interval from $t_{0}$ to $t$ is

$$
W\left(t_{0}, t\right)=\frac{1}{2} L(t) i^{2}(t)-\frac{1}{2} L\left(t_{0}\right) i^{2}\left(t_{0}\right)+\int_{t_{0}}^{t} \frac{1}{2} L\left(t^{\prime}\right) i^{2}\left(t^{\prime}\right) d t^{\prime},
$$

where the third term is the energy delivered by the active network to the permeance changing agent $\left[{ }^{15}\right]$.

From Eq. (13), the instantaneous power of a linear time-varying inductor with time-varying permeance and time-invariant turns equals

$$
\begin{aligned}
p_{L}(t) & =v(t) i(t)=\frac{d W\left(t_{0}, t\right)}{d t}= \\
& =i(t) L(t) \frac{d i(t)}{d t}+\frac{1}{2} i^{2}(t) \frac{d L(t)}{d t}+\frac{1}{2} i^{2}(t) \frac{d L(t)}{d t}= \\
& =i(t) L(t) \frac{d i(t)}{d t}+i^{2}(t) \frac{d L(t)}{d t} .
\end{aligned}
$$

Hence the voltage across the inductor

$$
v(t)=L(t) \frac{d i(t)}{d t}+i(t) \frac{d L(t)}{d t},
$$

i. e. an expression identical with (9).

\section{Conclusions}

1. A practical linear time-varying inductor can be implemented changing either the permeance or the turns of the inductor.

2. Voltage-current relations for linear inductors with time-varying permeance and time-varying turns are different due to various energy conversion processes.

3. For linear inductors with time-varying turns the voltage component proportional to the rate of inductance change is twice smaller than the corresponding voltage component for linear inductors with time-varying permeance.

\section{REFERENCES}

1. О я в е эр М., С а р в В., Изв. АН ЭССР, Физ. Матем., 26, № 3, 297-303 (1977).

2. О я в е э р М., С а р в В., Изв. АН ЭССР, Физ. Матем., 27, № 3, 342-348 (1978).

3. Сарв В. В., Батарин Г. Л., Оявеэр М. Р., Саккос Т. Ю., Хан с е н М. Я., Авт. свид. СССР № 624220, Бюл. изобр., № 34 (1978). 
4. О я в е э р M., С а к о с Т., С а р в В., Вентильно-индуктивные цепи непрерывного амплитудного регулирования переменного напряжения, Таллин, «Валгус», 1978.

5. Сооя в Ю., Л а у см а а Т., Изв. АН ЭССР, Физ. Матем., 27, № 4, 438-444 (1978).

6. К а а и к В., С ооя в Ю., Изв. АН ЭССР, Физ. Матем., 28, № 4, $352-358$ (1979)

7. С а к о с Т., Изв. АН ЭССР, Физ. Матем., 28, № 4, 346-351 (1979).

8. Саккос Т. Ю., Сооя в Ю. Э., В кн.: Проблемы преобразовательной техкики, ч. І, Киев, ИЭД АН УССР, 1979 , с. $62-65$.

9. С а р в В. В., В кн.: Источники электропитания со специальными характеристиблками, Киев, Наукова думка», 1979, с. 106-113.

10. К а а и к В. Т., С о о р в Ю. Э., В кн:: Теоретическая электротехника, вып. 28, Львов, Изд. Львовск. ун-та, 1980 , с. $87-96$.

11. С а р в В. В., С о о я в Ю. Э., Авт. свид. СССР № 777782, Бюл. изобр., № 41 (1980).

12. С ооя р в Ю. Э., В кн.; Уменьшение искажений в цепях с силовыми полупроводниковыми преобразователями, Таллин, ИТЭФ АН ЭССР, 1981, с. 16-19.

13. О я в е э М М. Р., В кн.: Уменьшение искажений в цепях с силовыми полупроводниковыми преобразователями, Таллин, ИТЭФ АН ЭССР, 1981, с. 50-53.

14. O j a ve e r, M., ENSV TA Toimet., Füüs, Matem., 30, № 3, 260-267 (1981).

15. Desoer, C. A., Kuh, E. S., Basic Circuit Theory, McGraw-Hill, Inc., New York, 1969.

Academy of Sciences of the Estonian SSR, Institute of Thermophysics and Electrophysics

Received Oct. 22,1981

gaivisy-9mi

V. SARV

\section{MUUTUVA KEERDUDE ARVUGA LINEAARSE PAISPOOLI ENERGIABILANSS NING PINGE JA VOULU SEOS}

On näidatud, et ajas muutuva induktiivsusega paispooli energiavahetus ümbritseva keskkonnaga vōib toimuda pōhiliselt kahel moel ning et sellele vastab kaks erinevat pinge ja voolu seost. Senituntud seos (9) vastab induktiivsuse muutmisele paispooli magnetilise juhtivuse muutmise teel. Sel puhul osalevad energiavahetuses paispooli klemmidega ühendatud elektriahel, paispooli magnetväli ning magnetilist juhtivust muutev tegur. Kui aga induktiivsust muudetakse voolustatud keerdude arvu muutes, nagu see on osutunud otstarbekaks mitmetes uutes voolusilumisskeemides $\left[{ }^{1-14}\right]$, siis toimub energiavahetus ainult paispooli klemmidega ühendatud elektriahela ja paispooli magnetvälja vahel. Artiklis esitatud uus pinge ja voolu seos (8), mis vastab niisugusele juhule, on tuletatud nii Faraday elektromagnetilise induktsiooni seaduse kui ka energiavahetuse iseloomule vastava paispooli hetkvõimsuse avaldise alusel.

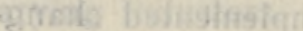

\section{B. $C A P B$}

\section{БАЛАНС ЭНЕРГИИ И СООТНОШЕНИЕ МЕЖДУ НАПРЯЖЕНИЕМ И ТОКОМ В ЛИНЕИНОМ ДРОССЕЛЕ С ПЕРЕМЕННЫМ ВО ВРЕМЕНИ ЧИСЛОМ ВИТКОВ}

Показано, что между дросселем с переменной во времени индуктивностью и окружающей средой существуют два внда энергообмена, которые и описываются, соответственно, двумя разлнчными соотношениями между напряжением и током дросселя. Известное соотношение (9) соответствует измененню нндуктивности с изменением магнитной проводимости дросселя. В этом случае в энергообмене участвуют электрнческая цепь, к которой присоединен дроссель, магнитное поле дросселя и фактор, обусловливающий изменение магнитной проводимости. Когда же индуктивность меняют изменением числа участвующих в работе витков (напр., в схемах сглаживания тока $\left.\left[{ }^{1-14}\right]\right)$, энергообмен пронсходит только между электрической цепью и магннтным полем. Новое соотношенне (8) выведено в статье двояко - исходя из закона электромагнитной индукцни Фарадея и исходя из выражения мгновенной мощности дросселя с соответствующим видом энергообмена. 